\title{
THE BUSINESS MANAGEMENT SKILLS OF SMALL INDUSTRIES ENTREPRENEURS AT CIBEUREUM DISTRICT SUKABUMI CITY
}

\author{
Herwan Abdul Muhyi \\ Department of Business Administration \\ Faculty of Social and Political Sciences, Universitas Padjadjaran \\ Email:herwan_am@yahoo.com,herwan_am@unpad.ac.id
}

\begin{abstract}
The City of Sukabumi is one of the city directly adjacent to Sukabumi Regency from the north, south, west and east. Potential major economies are from the industrial sector. This city does not have tourism potential of nature (natural tourism). In the industrial sector, the role of small businesses that have production activities play an important role in the economy of the city. The purpose of this study is to identify and explain the extent of the business management skills of small business entrepreneurs who perform production activities (small industries). This study describes the elements of business management skills that are run during this time. This study used a qualitative approach. This approach is intended to uncover the business management skills of small entrepreneurs in District of Cibeureum. To maintain the quality and validity of the data carried triangulation techniques.

The results showed that the business management skills of small entrepreneurs in the district of Cibeureum not comply with management standards. This means that there are still many elements of the business management skills that does not run properly. The best element is the human relations while the lowest is the accounting.
\end{abstract}

Keywords : Business management skills, small entrepreneurs

\section{KETERAMPILAN PENGELOLAAN BISNIS PARA PENGUSAHA KECIL DI KECAMATAN CIBEUREUM KOTA SUKABUMI}

\begin{abstract}
ABSTRAK
Kota Sukabumi merupakan salah satu kota yang berbatasan langsung dengan Kabupaten Sukabumi baik dari sisi utara, selatan, barat dan timur. Potensi perekonomian yang besar adalah dari sektor industri, mengingat Kota Sukabumi tidak memiliki potensi wisata alam (natural tourism). Pada sektor industri ini, peran pengusaha kecil yang memiliki aktivitas produksi memegang peran penting dalam perekonomian kota. Tujuan penelitian ini adalah untuk mengetahui dan menjelaskan sejauhmana keterampilan manajemen bisnis atau pengelolaan bisnis para pengusaha kecil yang melakukan aktivitas produksi (industri kecil). Penelitian ini menggambarkan elemen-elemen keterampilan pengelolaan usaha yang dijalankan selama ini. Penelitian ini menggunakan pendekatan kualitatif. Pendekatan ini dimaksudkan untuk mengungkap keterampilan pengelolaan bisnis dari para pengusaha kecil di Kecamatan Cibeureum. Hasil penelitian menunjukkan bahwa keterampilan pengelolaan bisnis para pengusaha kecil di Kecamatan Cibeureum Kota Sukabumi belum sesuai dengan standar pengelolaan. Artinya masih banyak elemen-elemen pengelolaan bisnis yang tidak berjalan sebagaimana mestinya. Elemen yang paling baik adalah human relations sedangkan yang paling rendah adalah keterampilan akuntansi.
\end{abstract}

Kata kunci: Keterampilan pengelolaan bisnis, pengusaha kecil 


\section{PENDAHULUAN}

Banyak sekali sektor bisnis skala besar berguguran karena ketidakmampuan manajemen dalam menghadapi terjangan krisis ekonomi global. Dan pada saat yang bersamaan para pengusaha kecil lebih kuat menghadapi krisis ini.

Namun demikian perlu dicermati, apakah daya tahan yang dimiliki para pengusaha kecil pada masa krisis disebabkan karena kekuatan manajerial mereka atau secara alamiah karena memang mereka tidak banyak berhubungan langsung dengan ekonomi global? Sehingga perubahan kurs mata uang asing yang sangat dramatis tidak berdampak secepat kepada eksistensi perusahaan besar.

Fenomena ini melatarbelakangi penulis untuk mengungkap sejauhmana keterampilan pengelolaan bisnis (business management skills) para pengusaha kecil. Agar kupasan keterampilan pengelolaan bisnis para pengusaha kecil lebih fokus dan mendalam, penulis melakukan penelitian di Kecamatan Cibeureum Kota Sukabumi.
Kota Sukabumi menarik untuk diteliti karena merupakan salah satu kota di Jawa Barat yang nyaris tidak memiliki potensi alam (natural resources) baik potensi tambang maupun potensi wisata alam (natural tourism). Otomatis Kota Sukabumi lebih mengandalkan pada sektor lain selain potensi alam dalam melaksanakan pembangunan kota, dan industri menjadi andalan utama perekonomian kota. Adapun Kecamatan Cibeureum merupakan salah satu kecamatan baru di Kota Sukabumi yang merupakan hasil pemekaran kota. Kecamatan Cibeureum juga berada di paling timur dan berbatasan langsung dengan Kabupaten Sukabumi.

Kecamatan Cibeureum Kota Sukabumi memiliki empat kelurahan yaitu Kelurahan Sindang Palay, Kelurahan Limus Nunggal, Kelurahan Babakan dan Kelurahan Cibeureum Hilir. Pada keempat wilayah kelurahan ini terdapat banyak industri kecil baik bidang makanan, minuman, pakaian, jasa dan lain-lain. Berikut disajikan sebaran industri kecil di Kecamatan Cibeureum Kota Sukabumi.

Tabel 1. Jumlah Industri Kecil di Kecamatan Cibeureum Kota Sukabumi

\begin{tabular}{|c|l|c|c|}
\hline \multirow{2}{*}{ No } & \multicolumn{1}{|c|}{ Kelurahan } & \multicolumn{2}{|c|}{ Industri Kecil } \\
\cline { 3 - 4 } & & Qty & \% \\
\hline 1 & Kelurahan Sindang Palay & 19 & 18,10 \\
\hline 2 & Kelurahan Limus Nunggal & 41 & 39,05 \\
\hline 3 & Kelurahan Babakan & 12 & 11,43 \\
\hline 4 & Kelurahan Cibeureum Hilir $\quad$ Jumlah & 33 & 31,43 \\
\hline \multicolumn{2}{|c|}{} & $\mathbf{1 0 5}$ & $\mathbf{1 0 0}$ \\
\hline
\end{tabular}

Sumber: Diskoperindag Kota Sukabumi (2012)

Pada tabel 1 terlihat bahwa Kelurahan Limus Nunggal sebagai kelurahan dengan jumlah industri kecil terbanyak. Adapun jumlah industri kecil paling sedikit adalah di Kelurahan Babakan. Sebaran untuk industri kecil di Kecamatan Cibeureum Kota Sukabumi lebih jelas disajikan pada diagram di bawah ini. 


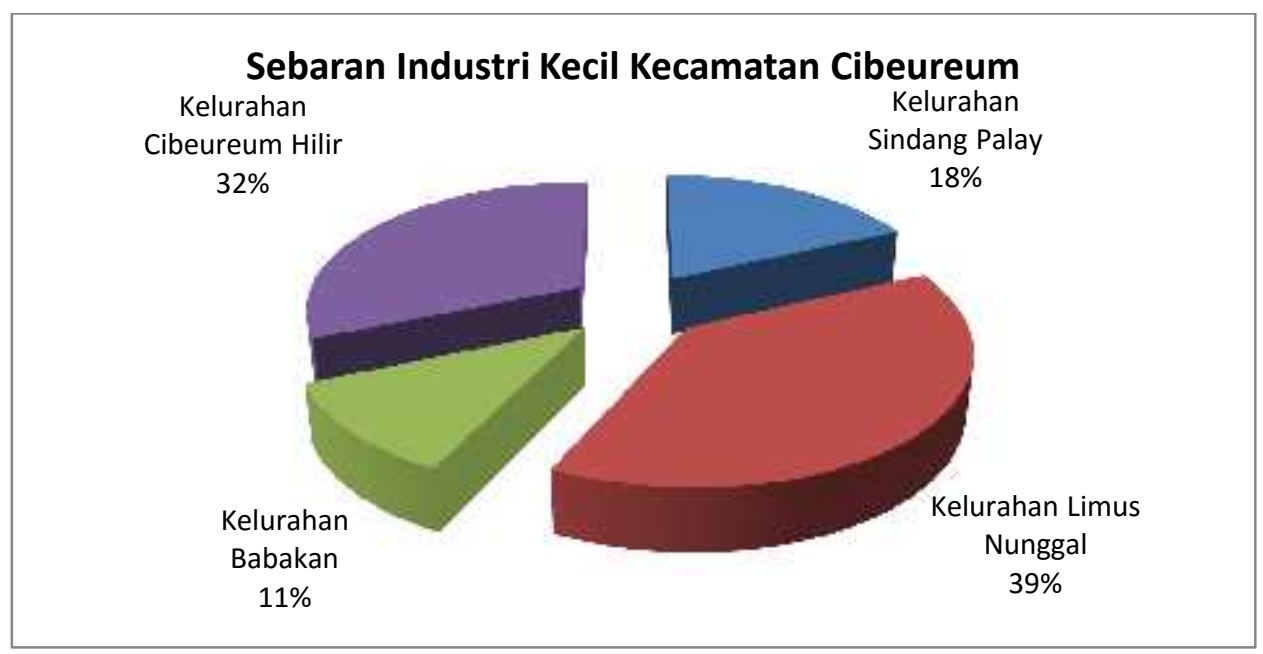

Gambar 1. Sebaran Industri Kecil Kecamatan Cibeureum

Sumber: Disperindagkop Kota Sukabumi, diolah peneliti Tahun 2016

Para pengusaha di Kecamatan Cibeureum bergerak pada berbagai bidang usaha. Adapun bidang usaha yang paling banyak adalah pada sektor industri makanan. Secara lengkap disajikan pada tabel di bawah ini:

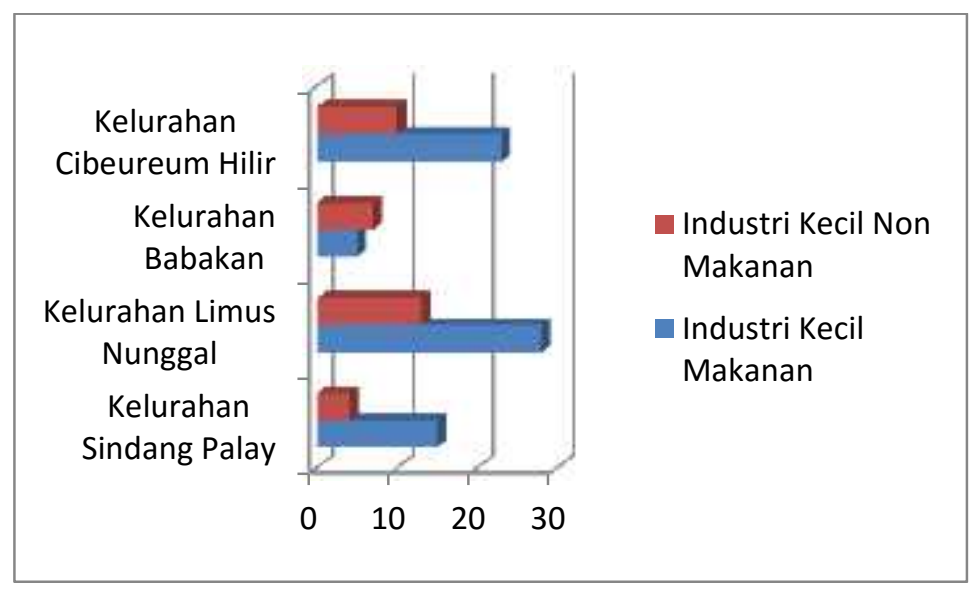

Gambar 2. Perbandingan Industri Makanan dan Non Makanan Kecamatan Cibeureum

Grafik di atas menunjukkan bahwa hampir semua kelurahan didominasi oleh industri kecil yang memproduksi makanan. Hanya satu kelurahan saja yang industri makanan lebih sedikit dari industri non makanan yaitu di Kelurahan Babakan. Tren ini sama dengan keadaan di kelurahan-kelurahan di Kota Sukabumi pada umumnya. Kuliner menjadi industri yang paling banyak karena memiliki karakteristik yang relatif mudah untuk dijalankan dan memiliki variasi yang sangat beragam. Selain itu potensi pasar dianggap sangat bagus karena Kota Sukabumi secara geografis berada di tengah-tengah wilayah Kabupaten Sukabumi yang memiliki potensi wisata alam sangat banyak.

Bagaimana dengan kondisi perusahanperusahaan itu sendiri bila dilihat dari perkembangan pengelolaan perusahaan? Peneliti akan menyajikan kondisi eksisting keterampilan para pengusaha di Kecamatan Cibeureum sebagai berikut:

Pertama, ketiadaan perencanaan dan penentuan tujuan menjadi salah satu indikasi yang muncul hampir dari seluruh pengusaha. 
Mereka menjalankan aktivitas usaha spontan saja tanpa ada schedule yang jelas dan tujuan yang jelas. Adapun tujuan yang mereka anggap ada hanyalah berupa keuntungan (profitabilitas) saja.

Kedua, kesulitan dalam melakukan pengelolaan keuangan dan pembukuan atau akuntansi sederhana yang berdampak pada ketidakjelasan alokasi dana dan rencana pertumbuhan membuat usaha mereka seolaholah jalan ditempat.

Fenomena dan permasalahan tersebut memotivasi penulis untuk menggali keterampilan pengelolaan bisnis (business management skills) para pengusaha yang mengelola bisnis pada industri skala kecil di Kecamatan Cibeureum Kota Sukabumi.

\section{TINJAUAN PUSTAKA}

Perkembangan kewirausahaan secara historis telah dimulai dari sejak berabad-abad Sebelum Masehi. Dengan kemampuan wirausaha dalam arti kemampuan dalam pengambilan resiko, berinovasi, menerapkan sistematika kerja, bangsa Mesir dapat membangun piramida, bangsa Cina dapat membangun tembok raksasa, dan Kerajaan Mataram Kuno dapat membangun Candi Borobudur. Kemudian pada abad pertengahan, VOC, perusahaan perniagaan Belanda, menjadi sistem pengumpul bahan mentah rempahrempah dari Nusantara untuk kepentingan memasok pasar Eropa adalah contoh usaha yang beresiko. Dimana sebelumnya telah dirintis pencarian rute ke Timur jauh oleh Marcopolo.

Berikut penulis uraikan perkembangan kewirausahaan mulai dari periode awal ketika istilah kewirausahaan mulai dipraktikkan. Perkembangannya secara historis diklasifikasikan menjadi empat periode sebagai berikut:

1) Perioda Awal (Earliest Period)

2). Abad Pertengahan (Middle Ages)

3). Abad ke 17 (17 $7^{\text {th }}$ Century)

4). Abad ke -18 (18 $8^{\text {th }}$ Century)
5). Abad ke 19 dan Abad ke $20\left(19^{\text {th }}\right.$ and $20^{\text {th }}$ Centuries) Hisrich, et, al. (2005, 6-7)

Konsep kewirausahaan pun kini banyak dikemukakan para ahli. Mereka mengemukakan konsep kewirausahaan secara bervariasi namun memiliki kesamaan. Hatten (1997:31) mengemukakan konsep kewirausahaan dan usaha kecil sebagai berikut:

"Entrepreneurship is the process of identifying opportunities for which marketable needs exist and assuming the risk of creating an organization to satisfy them. An entrepreneur needs the vision to spot opportunities and the ability to capitalize on them.

Small business management is the ongoing process of owning and operating an established business. A small business manager must be able to deal with all the challenges of moving the business forward.

An entrepreneur is a person who takes advantages of a business opportunity by assuming by financial material, and psychological risks of starting or running company."

Inti dari pendapat tersebut menyebutkan bahwa kewirausahaan adalah proses mengidentifikasi peluang yang dibutuhkan oleh pasar, mengelola risiko, visioner terhadap peluang dan mampu menjalankannya. Sedangkan manajemen usaha kecil adalah memiliki dan mengoperasikan bisnis yang didirikan disertai kemampuan menghadapi tantangan dan pergerakkan bisnis.

Adapun yang dimaksud dengan entrepreneur sendiri adalah seseorang yang mengambil keuntungan dari peluang bisnis yang melalui pengambilan resiko keuangan, material dan psikologis ketika merintis usahanya. Jadi, Haten menitikberatkan konsep kewirausahaan pada keberanian mengambil resiko, menangkap peluang bisnis dan mengoperasikan bisnis yang didirikan.

Lain halnya dengan Haten, Suryana (2003:13) lebih memandang kewirausahaan 
sebagai: "Suatu kemampuan kreatif dan inovatif (create new and different) yang dijadikan kiat, dasar, sumber daya, proses dan perjuangan untuk menciptakan nilai tambah barang dan jasa yang dilakukan dengan keberanian untuk menghadapi risiko.."

Inti dari empat cara-cara yang dikemukakan Suryana tersebut adalah kreativitas dan inovasi. Lebih jelas, Suryana (2003:2) mengemukakan:

"Kreativitas berarti kemampuan untuk menerapkan dan mengembangkan ide-ide baru dan cara-cara baru dalam pemecahan masalah dan menemukan peluang Sedangkan inovasi adalah kemampuan untuk menerapkan kreativitas dalam rangka pemecahan masalah dan menemukan peluang. Jadi kreativitas adalah kemampuan untuk memikirkan sesuatu yang baru dan berbeda, sedangkan inovasi merupakan kemampuan untuk melakukan sesuatu yang baru dan berbeda."

Konsep tersebut menjelaskan bahwa seorang wirausaha mampu mewujudkan ide usaha menjadi peluang. Peluang tersebut kemudian diterapkan atau dijalankan dan dikembangkan melalui penemuan cara-cara baru. Cara-cara baru tersebut kemudian diterapkan oleh wirausaha dalam rangka pengembangan usaha yang dikelolanya.

Kekuatan personal wirausaha merupakan modal yang sangat penting dalam rangka merintis, menjalankan dan mengembangkan usaha. Namun demikian pertumbuhan usaha memerlukan aspek pengelolaan bisnis untuk menjaga keberlangsungan dan menumbuhkan usaha. Ilmu dan seni pengelolaan atau yang dikenal dengan istilah manajemen merupakan keterampilan yang harus melekat pada seorang entrepreneur terlebih bagi pengusaha skala kecil dan menengah.

Manajemen merupakan suatu ilmu dan seni. Sebagai suatu ilmu, manajemen dapat diajarkan dan dapat memprediksi berbagai fenomena dan menjadi metode, cara, kerangka dan model dalam memecahkan masalah. Perkembangan manajemen sebagai ilmu juga berlangsung puluhan bahkan ratusan tahun.

Sebagai suatu seni, manajemen merupakan suatu seni mengelola. Adapun yang dikelola adalah sumber daya organisasi baik orang, barang, mesin, uang, pasar maupun metode. "Management is getting thing done through the efforts of other people" merupakan pengertian manajemen menurut Koontz and Donnel (1968). Sedangkan Stonner mendefinisikan bahwa manajemen merupakan suatu proses perencanaan, proses pengorganisasian, pengarahan serta pengawasan usaha-usaha dari para anggota organisasi beserta penggunaan sumber-sumber daya organisasi lain guna mencapai tujuan organisasi yang sudah lama ditetapkan.

Adapun elemen-elemen pengelolaan bisnis (business management skills) dikemukakan oleh Hisrich et al (2005:21) adalah sebagai berikut: a) Planning and goal setting, b) Decision making, c) Human relations, d) Marketing, e) Finance, f) Accounting, g) Management (People), h) Control, i) Negotiation, j) Venture launch, k) Managing growth.

\section{METODE PENELITIAN}

Objek penelitian ini adalah keterampilan pengelolaan bisnis (business management skills). Mengacu pada pendapat Husein Umar (2005:303), "Objek penelitian menjelaskan tentang apa dan atau siapa yang menjadi objek penelitian. Juga dimana dan kapan penelitian dilakukan. Bisa juga ditambahkan hal-hal lain jika perlu". Pada penelitian ini objeknya adalah apa yang diteliti yaitu keterampilan pengelolaan bisnis. Siapa yang menjadi objek adalah para pengusaha pada industri kecil di Kecamatan Cibeureum di Kota Sukabumi. Penelitian ini menggunakan pendekatan kualitatif. Pendekatan kualitatif dimaksudkan untuk menggali apa yang ada atau terjadi dibalik fenomena yang muncul dalam hal keterampilan pengelolaan bisnis para pengusaha kecil di Kecamatan Cibeureum. 
Analisis dan pembahasan yang akan dilakukan menggunakan mentode analisis deskriptif. Mengacu kepada pendapat Moh. Nazir (2005:54) mengemukakan bahwa: Metode ini digunakan untuk meneliti status sekelompok manusia, suatu objek, suatu set kondisi, suatu sistem pemikiran, ataupun suatu kelas peristiwa pada masa sekarang. Tujuan dari penelitian deskriptif ini adalah untuk membuat deskripsi, gambaran atau lukisan secara sistematis, faktual dan akurat mengenai fakta-fakta, sifat-sifat serta hubungan antar fenomena yang diselidiki.Dalam pelaksanaannya, teknik pengumpulan data yang dilakukan penulis yaitu: Observasi Langsung pada industri kecil, wawancara mendalam dengan para pengusaha dan karyawan industri kecil di Kecamatan Cibeureum dan studi dokumentasi baik dari perusahaan maupun dinas terkaiy.

Informan pada penelitian ini adalah para pengusaha industri skala kecil di Kecamatan Cibeureum Kabupaten Sukabumi. Selain itu juga dilakukan in-depth interview dengan konsumen dan pemerintah daerah.

Kredibilitas data penelitian ini dilakukan melalui berbagai upaya. Upaya-upaya yang dilakukan untuk menjamin kredibilitas data adalah sebagai berikut:

a. Perpanjangan Pengamatan

Peneliti melakukan pengamatan pada jangka waktu yang cukup lama. Apabila pada kasus tertentu membutuhkan informasi lebih lengkap maka peneliti melakukan pengamatan lebih jauh lagi di Kecamatan Cibeureum.

b. Meningkatkan Ketekunan

Upaya ini dilakukan dengan menelusuri secara teliti data dan informasi yang diperoleh. Hal ini dilakukan untuk mendapatkan hal-hal detil dari data dan informasi lapangan.

c. Triangulasi

Langkah ini dilakukan penulis dengan cara melakukan konfirmasi antar informan, data pengusaha industri kecil, karyawan serta pelanggan yang relevan.

\section{HASIL DAN PEMBAHASAN}

Seorang wirausaha selain memiliki karakteristik atau sifat wirausaha juga harus memiliki kemampuan manajemen atau pengelolaan. Gairah berwirausaha saja tidak cukup karena pada pelaksanaannya, menjalankan roda perusahaan membutuhkan keterampilan mengelola bisnis (business management skills).

Keterampilan mengelola bisnis merupakan aspek yang penting dalam rangka mencapai kemajuan usaha. Elemen untuk mengukur keterampilan seorang wirausaha menurut Hisrich et al (2005:21) terdiri dari 11 (sebelas) elemen.

\section{Keterampilan Merencanakan dan Menetapkan Tujuan}

Planning and goal setting, merupakan keterampilan merencanakan dan menentukan tujuan yang diharapkan. Dari perencanaanlah semua kegiatan dimulai agar tujuan tercapai sesuai dengan target yang diinginkan. Para pengusaha industri skala kecil di Kecamatan Cibeureum Kota Sukabumi pada umumnya tidak melakukan perencanaan. Mereka menjalankan usaha secara spontan saja. Hanya beberapa perusahaan saja yang menetapkan tujuan yakni berupa target penjualan secara harian dan bulanan. Tidak ada perusahaan yang melakukan perencanaan dan target secara berkala bulanan, tahunan, lima tahunan atau 10 tahunan.

Semua informan mengatakan bahwa mereka tidak memiliki desain perencanaan jangka pendek, menengah dan panjang. Setelah dilakukan pengecekan terhadap dokumendokumen yang ada di perusahaan, tidak ditemukan perencanaan yang tertulis dan sistematis.

Setelah dikonfirmasi mengapa hal ini terjadi, para pengusaha mengatakan bahwa mereka tidak mengetahui bagaimana cara menyusun 
perencanaan yang baik, merasa tidak perlu karena skala usaha masih kecil dan jawaban lainnya adalah yang penting usaha jalan dan terus berlangsung.

\section{Keterampilan Memutuskan}

Keterampilan ini sangat penting dimiliki oleh seorang wirausaha. Berbagai permasalahan yang dihadapi oleh seorang wirausaha menununtut mereka untuk dapat memilih alternatif yang tepat dalam rangka pemecahan masalah. Begitupun kemampuan mengambil keputusan diperlukan dalam rangka mengambil peluang yang dapat menguntungkan perusahaan.

Berdasarkan informasi dari para pengusaha, bahwa secara umum mereka tidak terlalu kesulitan kalau harus mengambil keputusan. Bagi mereka merintis dan menjalankan usaha sekarang ini adalah salah satu wujud keberanian. Salah satu pengusaha kecil berangapan "kalau saya tidak punya keberanian memutuskan tidak mungkin saya berbisnis." Namun pada sudut pandang lain beberapa pengusaha kecil mengatakan "kami berbisnis dan berani menjalankan bisnis karena tidak ada lagi pilihan."

Jadi apapun motifnya, para pengusaha kecil pada umumnya memiliki keberanian dalam memilih dan memutuskan. Namun demikian berdasarkan pengamatan peneliti, keberanian memutuskan dimiliki mereka pada hal-hal yang sifatnya rutin sehingga belum cukup teruji dalam hal memutuskan hal-hal yang bersifat besar dan berdampak signifikan dalam pengelolaan usaha.

\section{Keterampilan Human Relations}

Para pengusaha pada lingkup industri kecil di Kecamatan Cibeureum memiliki keterampilan yang sangat baik dalam hal hubungan manusiawi yang sudah menyentuh aspek empati (human relations). Hal ini diindikasikan dengan beberapa contoh perilaku mereka diantaranya: selalu menyapa dengan keramahan yang tinggi, transaksi dilakukan dengan variasi obrolan yang mengarah pada suasana akrab dan melayani komplain dengan terbuka.
Berdasarkan pengamatan peneliti, ada dua hal penting yang menyebabkan tingkat keterampilan human relations tinggi. Pertama, karena skala usaha yang masih kecil sehingga kemungkinan pelanggan berkomunikasi dengan pimpinan bahkan owners sangat terbuka. Kedua, nilai-nilai budaya Sunda di Kecamatan Cibeureum yang cenderung memiliki kebiasaan ramah tamah dan saling menghargai ucapan sehingga terjadi obrolan yang mengarah pada empati.

\section{Keterampilan Pengelolaan Pemasaran}

Marketing atau pemasaran, merupakan keterampilan yang harus dimiliki pengusaha dalam rangka mengenalkan dan menarik konsumen atau pelanggan. Bagaimana dengan para pengusaha kecil di Kecamatan Cibeureum?

Penambahan pangsa pasar terutama yang industri makanan seringkali terjadi karena kebetulan saja tanpa ada strategi yang direncanakan. Hal ini berimbas pada fluktuasi volume penjualan. Untuk industri non makanan terutama mebel atau perkayuan sudah mulai mendapatkan pasar dari luar kecamatan bahkan dari luar kota.

Upaya pemasaran seperti promosi, penentuan harga, perbaikan dan pengembangan produk belum dilakukan secara terencana. Ini menjadi salah satu penyebab peningkatan omset tidak tumbuh signifikan.

\section{Keterampilan Mengelola Keuangan}

Financial management, yakni kemampuan mengelola keuangan perusahaan. Sejauhmana para pengusaha industri kecil di Kecamatan Cibeureum Kota Sukabumi mampu melakukan pengelolaan keuangan tercermin dari deskripsi berikut yang merupakan hasil temuan lapangan.

Beberapa pengusaha kecil mengatakan "Kami mengalami kesulitan memisahkan uang hasil penjualan, uang untuk belanja modal, uang untuk tabungan dan uang untuk keperluan keluarga. Pernah beberapa kali mencoba dipilah namun berulang lagi pada kebiasaan lama." Tanggapan lainnya penulis dapatkan dengan 
pernyataan berbeda "Ketika pelanggan lagi banyak biasanya omset dan keuntungan pun bertambah, nah kelebihan uang ini seringnya kami gunakan untuk belanja keluarga atau kebutuhan lain seperti rekreasi." Menilik pada informasi tersebut, ada dua hal yang penulis peroleh mengenai pengelolaan keuangan: 1) Para pengusaha tidak memiliki keterampilan memilah keuangan dan atau desakan kebutuhan keluarga yang sangat kuat. 2) Para pedagang tidak membuat rencana keuangan (financial planning) sehingga ketika keuntungan meningkat bukannya dialokasikan untuk rencana perluasan usaha akan tetapi dianggap sebagai bonus saja yang dapat digunakan untuk aktivitas lain di luar kegiatan usaha.

\section{Keterampilan Akuntansi}

Pengelolaan keuangan perusahaan akan sangat terbantu apabila perusahaan melakukan aktivitas pembukuan atau dikenal dengan akuntansi. Untuk industri skala kecil sistem akuntansi sederhana akan sangat membantu.

Berdasarkan hasil pengamatan di lapangan, nampak ada tiga klasifikasi pengusaha yang ditemukan. Pertama, pengusaha yang tidak melakukan proses pencatatan transaksi dan pembukuan. Kedua, pengusaha yang melakukan proses pencatatan transaksi dan pembukuan secara manual. Ketiga, pengusaha yang mulai menggunakan komputer atau cash register dalam transaksi dan pembukuan. Dari ketiga golongan tersebut, golongan pertama yang paling banyak, Artinya sebagian besar pengusaha kecil di Kecamatan Cibeureum tidak melakukan pencatatan pertransaksi dan pembukuan. Hal ini berakibat ketidakjelasan dalam melakukan rekap pendapatan dan keuntungan usaha.

\section{Keterampilan Menggerakkan}

Sebagian besar pengusaha kecil di Kecamatan Cibeurem memiliki karyawan. Karyawan berfungsi menjalankan aktivitas perusahaan sesuai dengan arahan dari pengusaha (owners). Kemampuan menggerakkan orang lain dalam rangka mencapai tujuan ini merupakan bagian dari aktivitas manajemen. Mengacu kepada pendapat Siagian (2008:5) manajemen merupakan proses penyelenggaraan berbagai kegiatan dalam penerapan tujuan atau keterampilan memperoleh sesuatu hasil melalui orang lain. Diperoleh keterangan bahwa tidak ada masalah komunikasi dan keseganan, Namun latar belakang pendidikan dan keterampilan awal yang dimiliki menjadi permasalahan tertentu bagi pengusaha.

Setelah dikonfirmasikan kepada karyawan mengenai latar belakang pendidikan dan performa mereka dalam bekerja, sebagian dari karyawan malah mengemukakan rendahnya gaji atau upah mereka yang masih di bawah ketentuan upah minimum Kota Sukabumi. Hal ini menjadi bagian tak terpisahkan dalam hal keterampilan menggerakkan karyawan dengan kompensasi yang terbatas tetapi ingin kerjanya bagus. Pengusaha harus berpikir dan mencari alternatif pemecahan masalah ini.

Hasil riset menunjukkan, rupanya sulit bagi pengusaha untuk menghadapi situasi ini, karena sebagian besar dari para pengusaha ini juga bukan dari universitas apalagi dengan latar belakang pendidikan bisnis atau manajemen. Kondisi lack of management para pengusaha kecil ini berimbas pada tingginya tingkat keluar masuk karyawan (turnover).

\section{Keterampilan Mengawasi}

Pada umumnya pengusaha pada industri kecil di Kecamatan Cibeureum memahami makna dan manfaat pengawasan. Mereka paham bahwa pengawasan merupakan pengamatan dan pengendalian terhadap aktivitas para pekerja. Jadi pada elemen ini tidak banyak kesulitan yang dihadapi karena hirarki organisasi yang mereka miliki masih sederhana dan rata-rata owner terjun langsung sebagai pengelola.

Kelemahannya adalah tidak adanya proses pencatatan terhadap pelanggaran, penyimpangan maupun kesalahan yang terjadi dari waktu ke waktu. Hal ini acapkali menyebabkan terjadinya kesalahan yang sama. 


\section{Keterampilan Negosiasi}

Negotiation skill yaitu sejauhmana seorang pengusaha mampu bernegosiasi atau meningkatkan posisi tawarnya dengan berbagai pihak yang terkait dengan bisnis yang digeluti. Para pengusaha mengaku keterampilan negosiasi dibutuhkan saat membeli bahan mentah atau bahan baku kepada supplier atau pemasok. Beberapa pengusaha yang menjadi informan menganggap bahwa dirinya memiliki kemampuan dalam menawar harga kepada pemasok dan meminta pembayaran diakhir atau bertahap. Kemampuan ini menurut mereka sangat membantu dalam menjalankan aktivitas usaha.

Menawarkan produk dengan kuantitas yang lebih dari rencana pembeli atau menawarkan lini produk lain kepada pembeli juga sudah dimiliki oleh sebagian besar pengusaha kecil di Kecamatan Cibeureum. Namun untuk hal yang lebih besar seperti negosiasi dalam pengembangan bisnis dan bekerjasama dengan berbagai pihak, belum begitu nampak di kalangan para pengusaha industri kecil di Kecamatan Cibeureum ini.

\section{Keterampilan Peluncuran Usaha/Produk Baru}

Upaya pengembangan bisnis akan berjalan apabila disertai keterampilan meluncurkan usaha/produk baru (venture launch). Terkait dengan para pengusaha kecil di Kecamatan Cibeureum Kota Sukabumi diperoleh informasi sebagai berikut.

Menurut informan yang pernah membuka cabang usaha, membuka cabang usaha baru bukan hal mudah. "Tantangan yang dihadapi pada waktu membuka cabang usaha adalah pemilihan tempat, persiapan tempat, menghitung modal dan orang yang akan bekerja. Alhamdulillah walaupun butuh waktu agak lama, akhirnya jalan juga."

Dari semua informan, sebagian besar belum mengalami pembukaan usaha atau cabang baru. Namun untuk peluncuran produk baru hampir semua informan pernah melakukan. Namun tidak ada persiapan khusus seperti promosi berupa peluncuran produk atau membuat brosur khusus. Sebagian besar pengusaha ketika memperkenalkan produk baru seringkali menggunakan komunikasi lisan.

\section{Keterampilan Mengelola Perubahan}

Managing growth diperlukan untuk mempersiapkan dan mengelola pertumbuhan usaha. Keterampilan para pengusaha kecil dalam hal ini belum memenuhi syarat untuk mengelola pertumbuhan. Hal ini tercermin apabila ada penambahan ukuran (size) perusahaan baik berupa penambahan karyawan, penambahan produk, peningkatan omset maupun pengembangan organisasi perusahaan berupa cabang baru.

Salah satu informan mengatakan "Walaupun membutuhkan karyawan tambahan tetapi mengurusi yang ada saja tidak mudah, susah diatur." Informasi ini menunjukkan bahwa perubahan size atau ukuran organisasi belum disertai keterampilan pengelolaan. Kasus lain misalnya, ada perusahaan yang sudah cukup bagus namun enggan buka cabang. Alasannya adalah kalau buka cabang baru sulit mencari orang yang dapat dipercaya untuk mengelola. Jadi pengusaha ini lebih memilih fokus pada tempat usaha yang ada saja.

Lack of managing growth atau ketidakmampuan dalam mempersiapkan dan mengelola perubahan menjadi penyebab skala industry kecil di Kecamatan Cibeureum sulit beranjak ke level yang lebih besar. Ketakutan akan perubahan ini menjadi salah satu kunci lambatnya perkembangan industri kecil.

\section{SIMPULAN}

Penelitian ini menyajikan 11 (sebelas) keterampilan pengelolaan bisnis yang dimiliki oleh para pengusaha di industri kecil Kecamatan Cibeureum Kota Sukabumi. Keterampilan tersebut adalah: perencanaan dan penetapan tujuan, keterampilan memutuskan, human 
relations, pengelolaan pemasaran, keuangan, akuntansi, keterampilan menggerakkan, mengawasi, negosiasi, peluncuran usaha baru dan keterampilan mengelola perubahan.

Elemen keterampilan pengelolaan bisnis yang dikategorikan sudah dimiliki dengan baik oleh para pengusaha kecil adalah human relations dan keterampilan negosiasi. Sedangkan yang belum nampak dilaksanakan adalah keterampilan akuntansi dan keterampilan mengelola perubahan. Jadi secara keseluruhan elemen-elemen keterampilan pengelolaan bisnis para pengusaha industri kecil di Kecamatan Cibeureum Kota Sukabumi perlu ditingkatkan dalam rangka mengembangkan usaha.

\section{DAFTAR PUSTAKA}

Hisrich, Robert D, Peter Michael P and Shepherd Dean A. 2005. Entrepreneurship, Sixth Edition. NewYork: McGrawHill.

Hatten, Timothy S. 1997. Small Business Management: Entrepreneurship and Beyond. South-Western: Cengange Learning Husein Umar, 2005, "Metode Penelitian Untuk Skripsi dan Tesis Bisnis", Jakarta : PT. Raja Grafindo Persada.

Koontz, Harold and O'Donnell, Cyrill. 1968. Principles of Management: An Analysis of Managerial Functions, 4th Ed., New York: McGraw-Hill.

Nazir, Moh. 2005. Metode Penelitian. Bogor: Ghalia Indonesia.

Stoner, James AF, Freeman, R. Edward, Gilbert, Daniel R. Management Sixth Edition. Pearson Education

Sugiyono. 2014. Metode Penelitian Kuantitatif Kualitatif Dan R\&D. Bandung: CV. Alfabeta.

Suryana. 2003. Kewirausahaan. Jakarta: Salemba Empat 